Journal of Advanced Research in Applied Sciences and Engineering Technology

\title{
The Green Logistics Idea Using Vacuum Insulation Panels (VIPs) For Freezer Logistics Box in Normal Truck
}

\author{
Piyanut Saengsikhiao ${ }^{1}$, Juntakan Taweekun ${ }^{2,}{ }^{*}$, Kittinan Maliwan², Somchai Sae-ung ${ }^{2}$, \\ Thanansak Theppaya² \\ 1 Energy Technology Program, Faculty of Engineering, Prince of Songkla University, Hat Yai, Songkhla 90112, Thailand \\ 2 Department of Mechanical Engineering, Faculty of Engineering, Prince of Songkla University, Hat Yai, Songkhla 90112, Thailand
}

\section{ARTICLE INFO}

\section{Article history:}

Received 24 July 2020

Received in revised form 31 August 2020

Accepted 9 September 2020

Available online 14 November 2020

\section{ABSTRACT}

\begin{abstract}
This research presents the green logistics using vacuum insulation panels (VIPs) for freezer logistics box in normal trucks. The materials were Vacuum Insulation Panels (VIPs) with polyurethane foam box compared to polyurethane foam box that thermal conductivity for polyurethane foam and Vacuum Insulation Panels (VIPs) at $>20$ and < $7 \mathrm{~mW} / \mathrm{m}$.K. The vacuum Insulation Panels (VIPs) with polyurethane foam box design with VIP inside the polyurethane foam protect some impact from losing vacuum that loss thermal resistance. According to the result, after 24 hours, the ice-cream temperature of polyurethane foam box that lost 6 Degree Celsius, calculated as $30.00 \%$. Besides, the ice-cream temperature of that vacuum Insulation Panels (VIPs) with a polyurethane foam box has lost 1.5 Degrees Celsius, counted as $7.5 \%$, and compared with stating temperature at -20 Degrees Celsius. The result represents icecream quality after testing that shows the ice-cream condition in VIP Box still freezing, and ice cream condition in the normal box is melt. This research can be applied to a cold room or freezer room in supermarkets, factories, distribution centers, and VIPs that can result from electricity saving for compressors or cold trucks and freezer trucks that can get the result of fuel-saving for engines.
\end{abstract}

\section{Keywords:}

VIP, logistics box; green logistics; environmentally friendly

\section{Introduction}

Refrigeration accounts for $15 \%$ approximately of the total energy consumption in a household, consuming $6 \%$ of the total electrical energy produced worldwide [1-2]. Heat gain load has a significant load at $57 \%$ from total in the refrigerator, as shown in Figure 1 [3] implies the effect of power computation of the refrigeration system. The best options for reducing energy consumption are high energy efficiency and an efficient energy-management system [4]. An excellent example of energy savings in refrigeration systems is shown in the figure below [5]. Energy savings in refrigeration

\footnotetext{
* Corresponding author.

E-mail address: jantakan.t@psu.ac.th, juntakan2016@gmail.com
}

https://doi.org/10.37934/araset.21.1.1521 
systems can be achieved through decreased power consumption of the compressor, as this is the component that utilizes the most energy [6]. Vacuum Insulation Panels (VIPs) used to reduce heat gain load and get energy saving for refrigeration system $21 \%$ by installing VIPs $56 \%$ from total coverage area refrigerators [7-8].

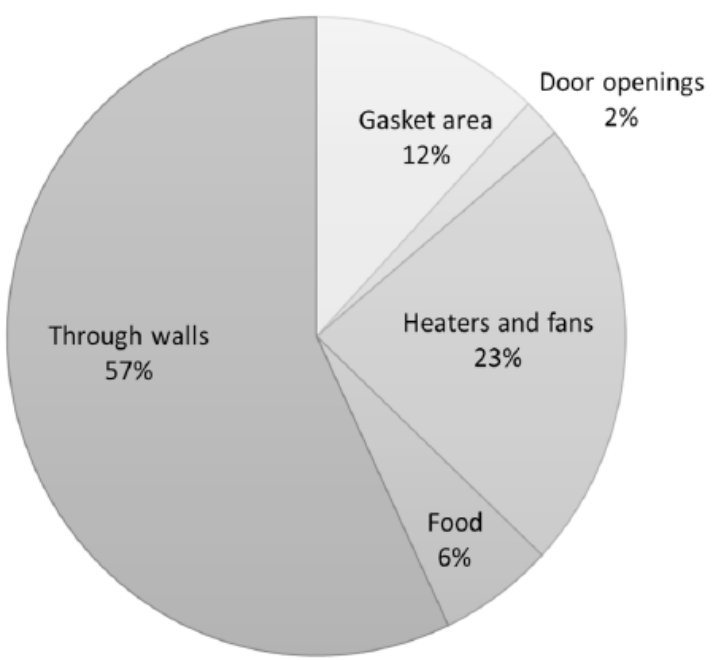

Fig. 1. Heat gain areas in refrigerator [3]

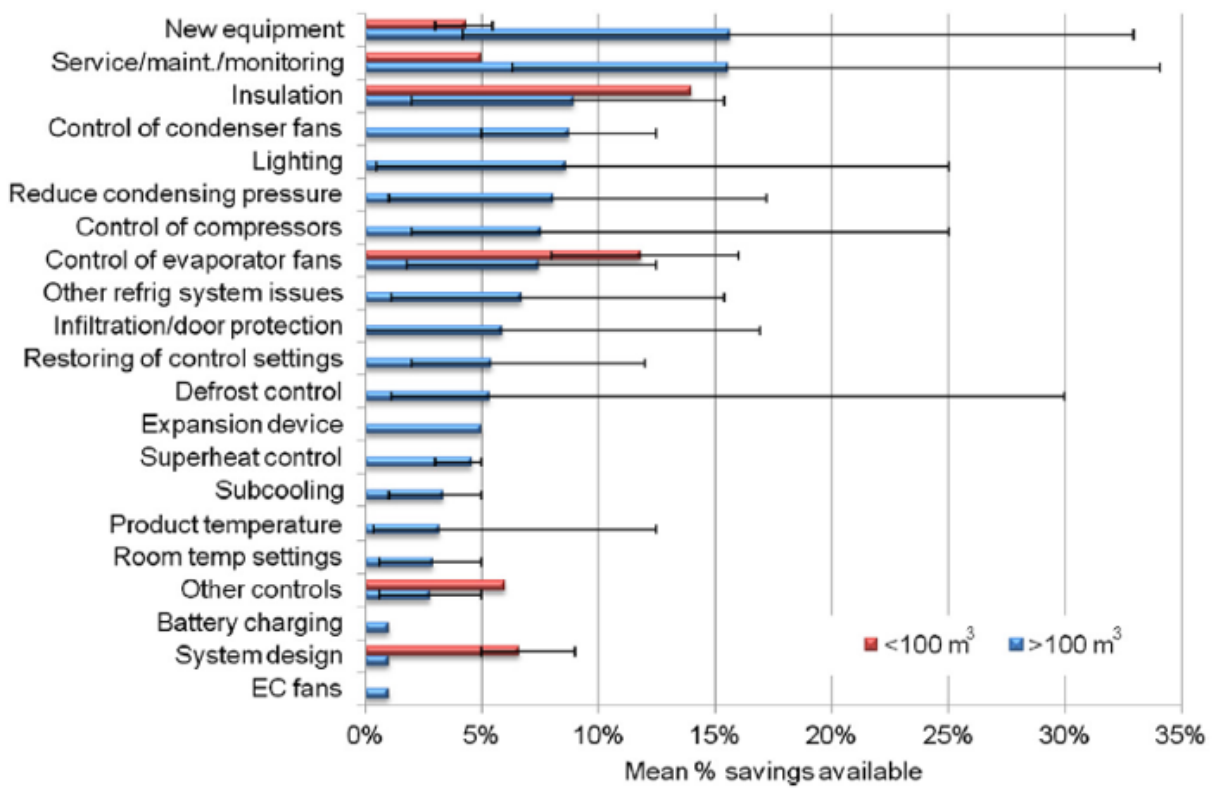

Fig. 2. Examples of energy savings in refrigeration systems [4]

Nowadays, the logistics model uses a frozen truck with the temperature at -25 to -23 degrees celsius, chiller trucks 0 to -2 degrees from the factory to the distribution center, and end-user. The type and size of rucks in this model will differ from length to the destination or product type [9-10]. When using many types or many trucks, the cost will be high and difficult to control. The green logistics model happens to solve the effect of environmental from logistics, such as fuel in logistics and carbon dioxide from engines [11-12]. This research will present the idea of the green logistics using vacuum insulation panels (VIPs) for freezer logistics box in a normal truck that use vacuum insulation panels (VIPs) that u-value better than polyurethane foam $80 \%$ as shown in Figures 3 and 4 [13-14]. The green logistics model can only use with normal trucks by use VIPs box and cooling supply 
by the cold pack or freezer pack because it can save the expenditure of freezer trucks and normal trucks [15-16].

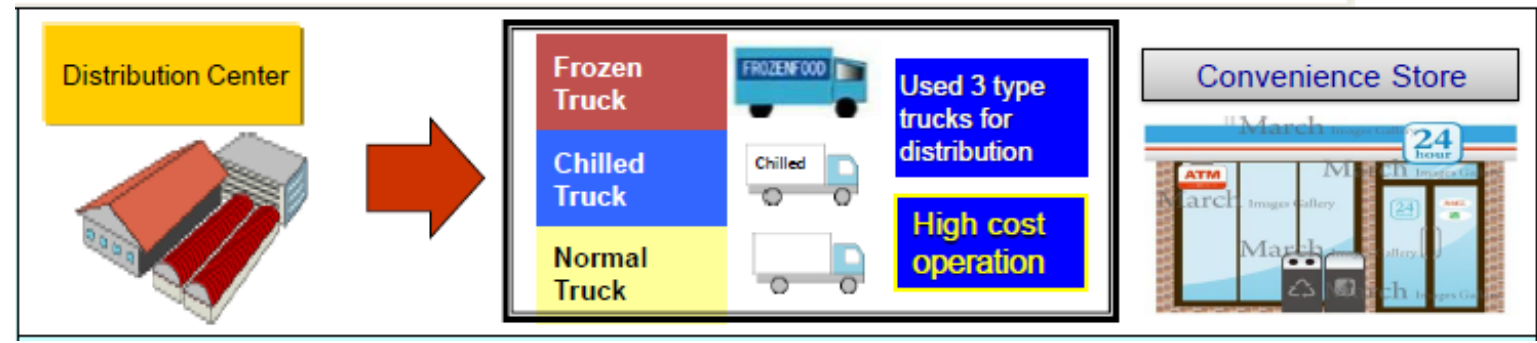

Fig. 3. Current Logistics model

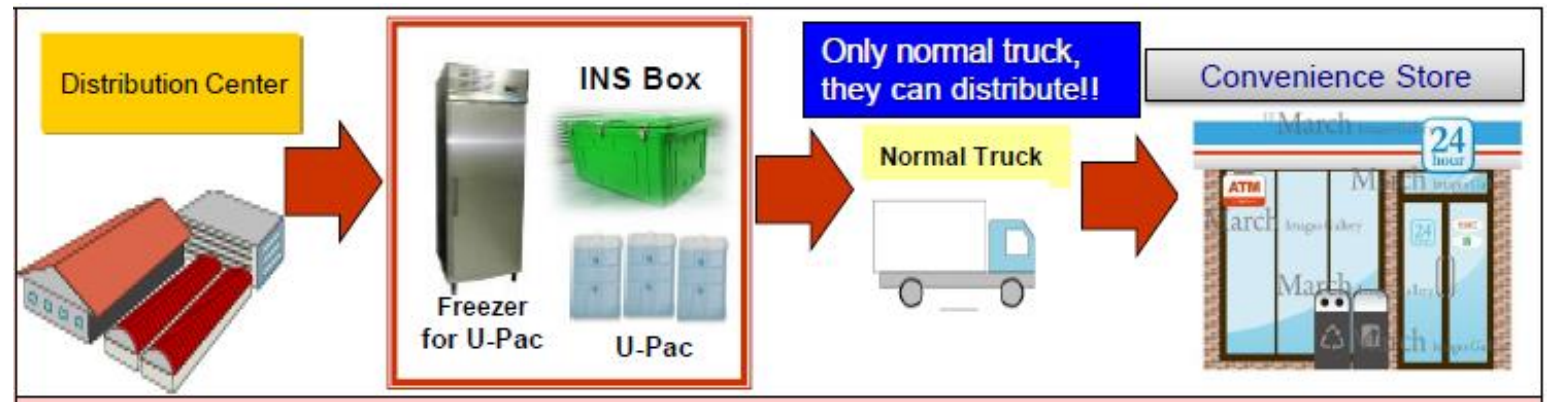

Fig. 4. Green Logistics model

\section{Materials and Methods}

The materials were vacuum Insulation Panels (VIPs) with polyurethane foam box comparing with polyurethane foam box that thermal conductivity for polyurethane foam and Vacuum Insulation Panels (VIPs) at $>20$ and $<7 \mathrm{~mW} / \mathrm{m} . \mathrm{K}$ [17], respectively. Besides, the IPs insulation was better as showing the thermal conductivity of insulation in Figure 5 below. The vacuum Insulation Panels (VIPs) with polyurethane foam box design helps to protect some impact from losing vacuum that loss thermal resistance, as shown in Figure 6 below. Therefore, The VIPs box design should keep the temperature for the product's quality, as shown in Figure 7 below 11 [18]. The thickness of VIPs was $35 \mathrm{~mm}$ while the thickness of PU foam inside and outside layer was $2.5 \mathrm{~mm}$, as shown in Figure 8 . The thickness of VIPs was lower than another insulation [19], as shown in Figure 8 below, which can design to improve thermal conductivity with another insulation [20].

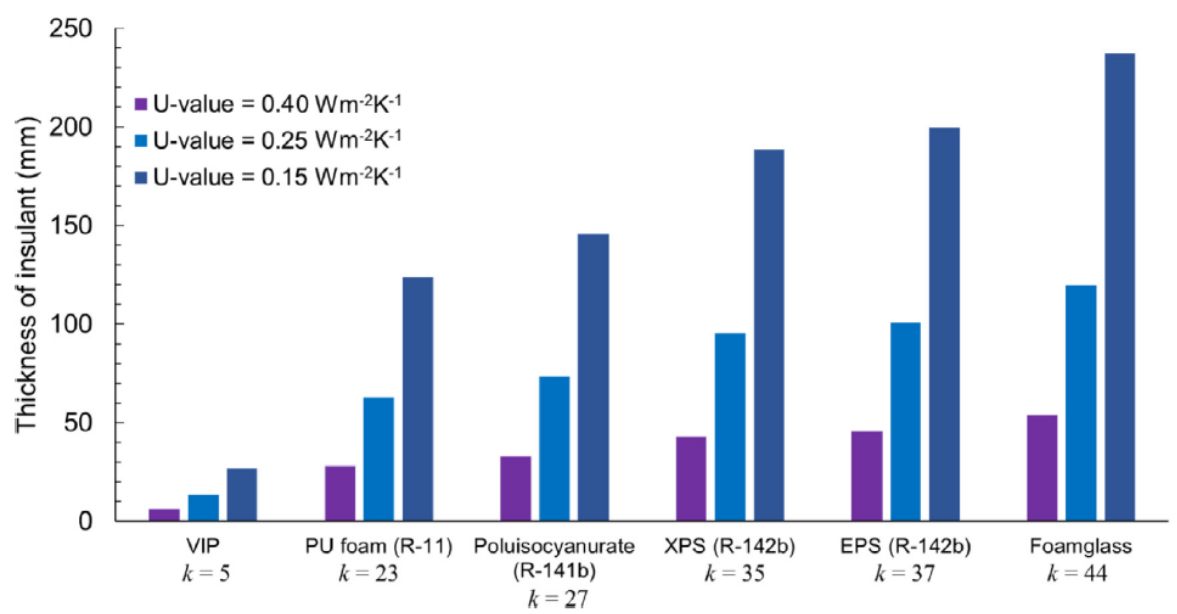

Fig. 5. thermal conductivity of insulation [1] 


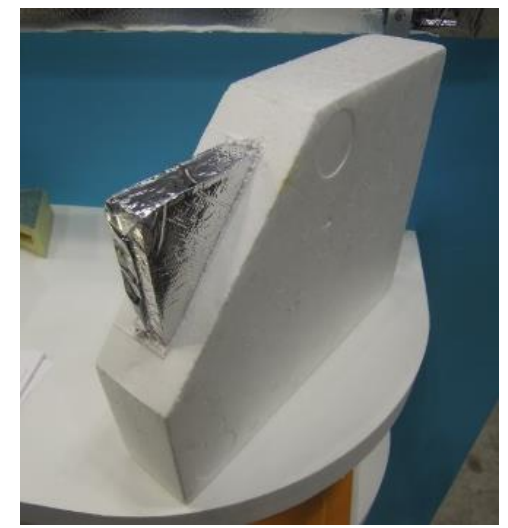

Fig. 6. VIPs box design [8]
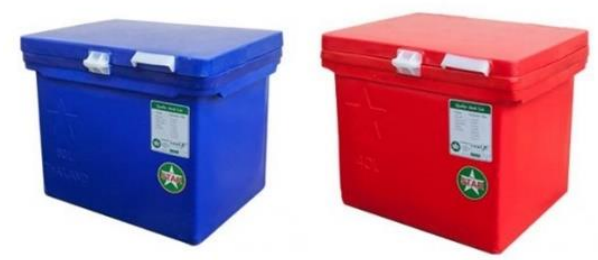

Fig. 7. Blue: VIPs Box, Red: PU Box

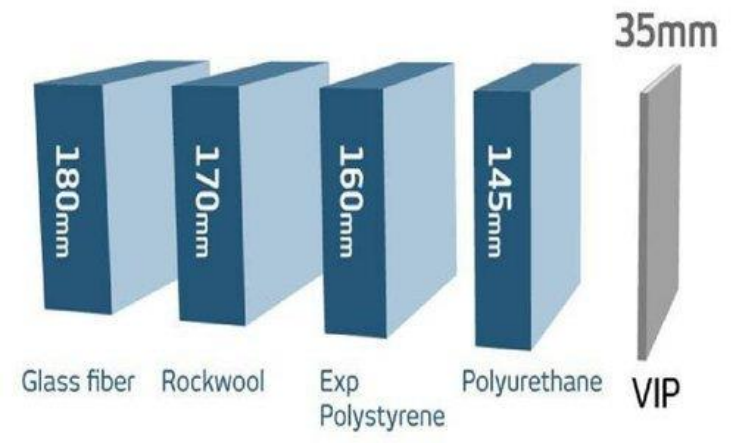

Fig. 8. Thickness of insulation

\section{Results and Discussion}

Keeping ice-cream's temperature by freezing with dry ice $6 \mathrm{~kg}$ for keep ice cream $1.88 \mathrm{~kg}$ with temperature not over than -18 degrees celsius, as shown in Figure 9 [21], indicates the Vacuum Insulation Panels (VIPs) with polyurethane foam box can keep temperature better than polyurethane foam box at the average of $24.58 \%$. The ice-cream temperature starts at -20 degrees celsius. After 12 hours, ice-cream in the polyurethane foam box temperature has lost 2 degrees celsius or calculated as $10.00 \%$. In contrast, the ice-cream temperature of vacuum Insulation Panels (VIPs) with polyurethane foam box has no temperature loss, compare with stating temperature. After 24 hours, the ice-cream temperature of polyurethane foam box has lost 6 degrees celsius, or $30.00 \%$, but the ice-cream temperature of Vacuum Insulation Panels (VIPs) with polyurethane foam box has loss 1.5 degrees celsius, which calculated as $7.5 \%$, compared with stating temperature. After 36 hours, the ice-cream temperature of polyurethane foam box that lost 9.5 degrees celsius, or $47.50 \%$. However, the ice-cream temperature of Vacuum Insulation Panels (VIPs) with polyurethane foam box has loss 3.5 degrees celsius, or $17.5 \%$, compared with stating temperature, shown in Figure 10 below. 


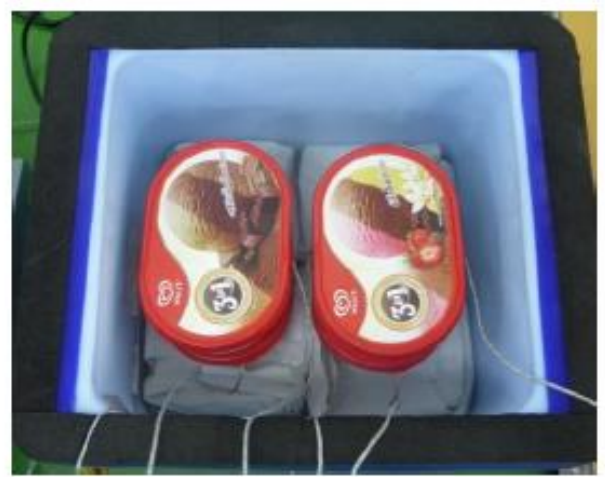

: Ice cream 4 boxes $(1.88 \mathrm{~kg})$ : Dry lce Weight $6 \mathrm{~kg}$.

Fig. 9. The freezing supply by dry ice $6 \mathrm{~kg}$ for keep ice cream $1.88 \mathrm{~kg}$ in temperature not over than -18 Degree Celsius [11]

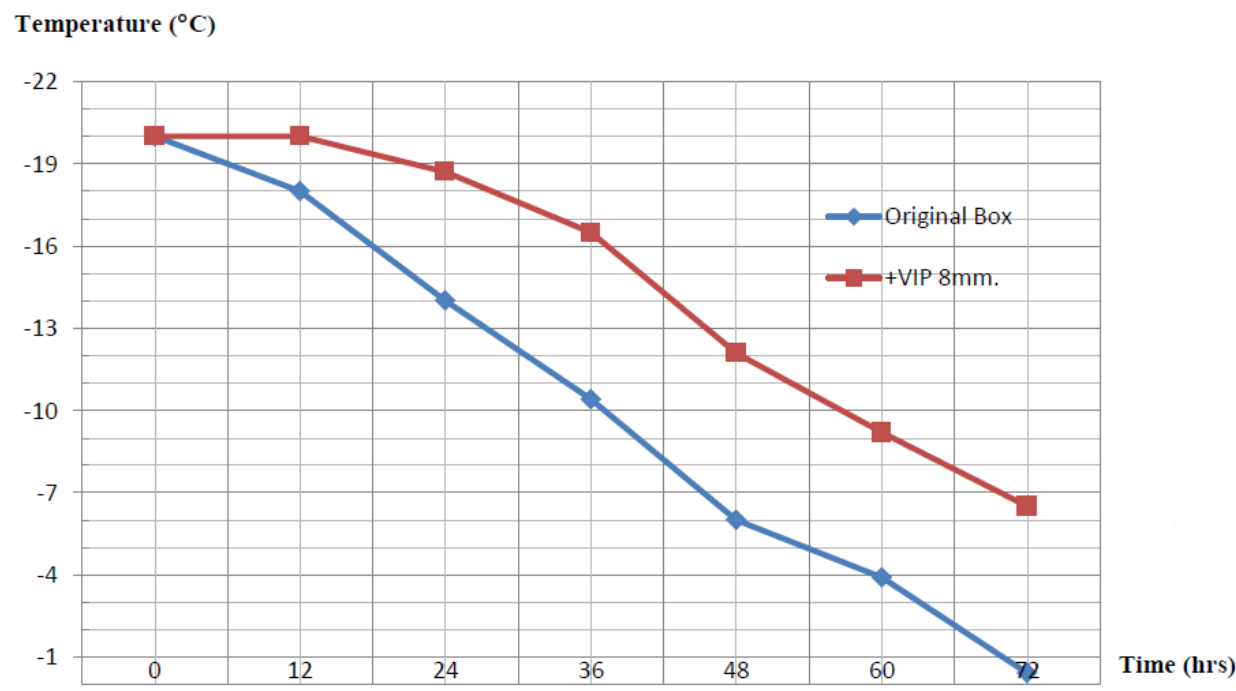

Fig. 10. The result of ice-cream temperature

After 48 hours, the ice-cream temperature of polyurethane foam box has lost 14.0 degrees celsius or counted as $70.00 \%$. However, the ice-cream temperature of Vacuum Insulation Panels (VIPs) with polyurethane foam box has lost 8.0 degrees celsius, which is calculated to be $40.00 \%$, compared with stating temperature. After 60 hours, the ice-cream temperature of polyurethane foam box has lost 16.0 Degree celsius, $80.00 \%$, but the ice-cream temperature of Vacuum Insulation Panels (VIPs) with polyurethane foam box has lost 11.0 degrees celsius, $55.00 \%$, compared with stating temperature. After 72 hours, the ice-cream temperature of polyurethane foam box has lost 19.5 degrees celsius, $97.50 \%$, but the ice-cream temperature of that vacuum Insulation Panels (VIPs) with polyurethane foam box has lost 13.5 degrees celsius or counted as $67.50 \%$, compared with stating temperature. The result of ice- cream quality after testing indicates that the ice-cream condition in VIP Box still freezing and ice cream condition in the usual box is melt, as shown in Figure 11 below. 

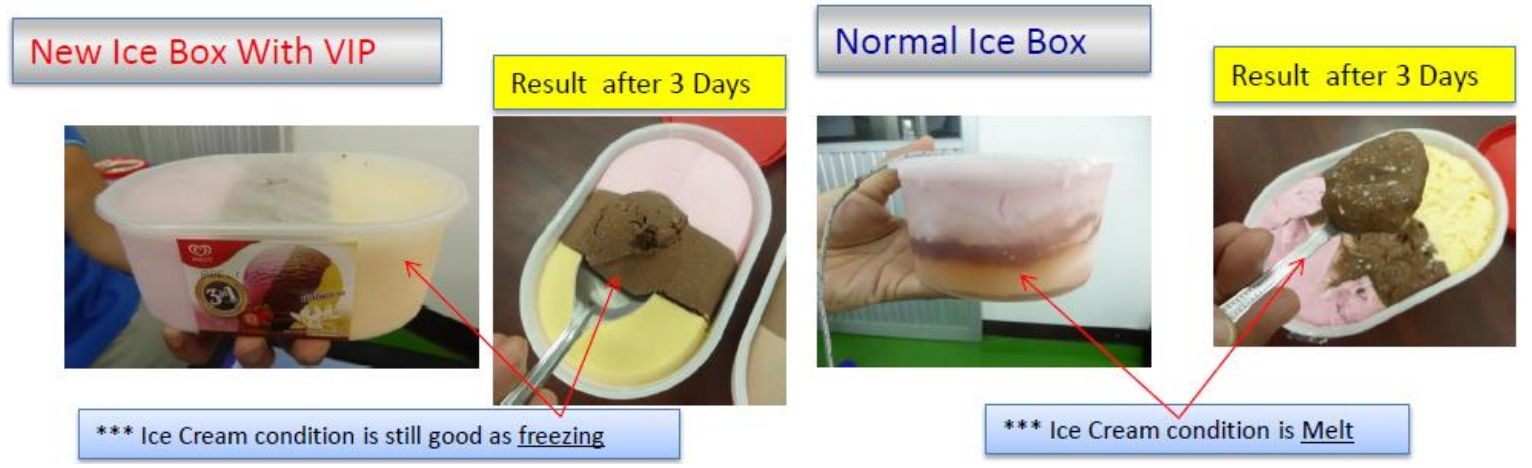

Fig. 11. The result of ice-cream condition

Typically, the freezer product manufacturer keeps storage temperature at -25 to -23 degrees celsius to keep freezer product temperature at -18 degrees celsius. The result of ice-cream's temperature of the polyurethane foam box for 24 hours was at -18.5 degrees celsius, which is over than -18 degrees celsius means the delivery of freezer product by freezer trucks has no difference in 24 hours from origin to destination. For example, freeze products to the distribution center, hub, or shops. Thus, logistics managers can change from frozen trucks to standard trucks that can save trucks' fuel and investment costs. Also, using green logistics that has low fuel consumption and environmentally friendly. The result can be applied to another logistics type, such as air or sea freight and train.

\section{Conclusions}

Researchers should apply the cold room or freezer room in supermarkets, factories, and distribution centers, with VIPs that can get the result of electricity saving for compressors or cold trucks, as well as freezer trucks that can get the result of fuel-saving for engines.

\section{Acknowledgement}

This study was supported by Prince of Songkla University and SANYO S.M.I. (Thailand) Co., Ltd. This research was funded by Prince of Songkla University and SANYO S.M.I. (Thailand) Co., Ltd.

\section{References}

[1] Kuo, Chung-Feng Jeffrey, Chieh-Hung Lin, and Ming-Hao Lee. "Analyze the energy consumption characteristics and affecting factors of Taiwan's convenience stores-using the big data mining approach." Energy and Buildings 168 (2018): 120-136. https://doi.org/10.1016/i.enbuild.2018.03.021

[2] Saengsikhiao, Piyanut, Juntakan Taweekun, Kittinan Maliwan, Somchai Sae-ung, and Thanansak Theppaya. "Investigation and Analysis of R463A as an Alternative Refrigerant to R404A with Lower Global Warming Potential." Energies 13, no. 6 (2020): 1514. https://doi.org/10.3390/en13061514

[3] Shen, Hanyan, Ke Xu, and James Freihaut. "A statistical study on energy performance of US convenience stores: Investigation of factors and bench marking on store energy use." Energy and Buildings 183 (2019): 792-802. https://doi.org/10.1016/j.enbuild.2018.10.018

[4] Tassou, S. A., Y. Ge, A. Hadawey, and Doug Marriott. "Energy consumption and conservation in food retailing." Applied Thermal Engineering 31, no. 2-3 (2011): 147-156.

https://doi.org/10.1016/j.applthermaleng.2010.08.023

[5] Wang, An-Ping, and Pau-Lo Hsu. "The network-based energy management system for convenience stores." Energy and buildings 40, no. 8 (2008): 1437-1445.

https://doi.org/10.1016/j.enbuild.2008.01.007 
[6] Chou, Ding-chin, Ching-Shan Chang, and Yong-Zhi Hsu. "Investigation and analysis of power consumption in convenience stores in Taiwan." Energy and Buildings 133 (2016): 670-687.

https://doi.org/10.1016/i.enbuild.2016.10.010

[7] Evans, J. A., E. C. Hammond, A. J. Gigiel, A. M. Fostera, L. Reinholdt, K. Fikiin, and C. Zilio. "Assessment of methods to reduce the energy consumption of food cold stores." Applied Thermal Engineering 62, no. 2 (2014): 697-705. https://doi.org/10.1016/i.applthermaleng.2013.10.023

[8] Chaomuang, Nattawut, Onrawee Laguerre, and Denis Flick. "Dynamic heat transfer modeling of a closed refrigerated display cabinet." Applied Thermal Engineering 161 (2019): 114138.

https://doi.org/10.1016/i.applthermaleng.2019.114138

[9] Chaomuang, Nattawut, Onrawee Laguerre, and Denis Flick. "A simplified heat transfer model of a closed refrigerated display cabinet." Thermal Science and Engineering Progress 17 (2020): 100494.

https://doi.org/10.1016/i.tsep.2020.100494

[10] Evans, J. A., S. Scarcelli, and M. V. L. Swain. "Temperature and energy performance of refrigerated retail display and commercial catering cabinets under test conditions." International Journal of Refrigeration 30, no. 3 (2007): 398-408.

https://doi.org/10.1016/i.ijrefrig.2006.10.006

[11] D'Agaro, P., G. Croce, and G. Cortella. "Numerical simulation of glass doors fogging and defogging in refrigerated display cabinets." Applied thermal engineering 26, no. 16 (2006): 1927-1934.

https://doi.org/10.1016/i.applthermaleng.2006.01.014

[12] de Frias, J. Atilio, Yaguang Luo, Bin Zhou, Boce Zhang, David T. Ingram, Keith Vorst, Jeffrey K. Brecht, and John Stommel. "Effect of door opening frequency and duration of an enclosed refrigerated display case on product temperatures and energy consumption." Food Control 111 (2020): 107044.

https://doi.org/10.1016/i.foodcont.2019.107044

[13] Månsson, Tommie, Adones Rukundo, Magnus Almgren, Philippas Tsigas, Christian Marx, and York Ostermeyer. "Analysis of door openings of refrigerated display cabinets in an operational supermarket." Journal of Building Engineering 26 (2019): 100899. https://doi.org/10.1016/i.jobe.2019.100899

[14] Chaomuang, Nattawut, Denis Flick, Alain Denis, and Onrawee Laguerre. "Experimental analysis of heat transfer and airflow in a closed refrigerated display cabinet." Journal of Food Engineering 244 (2019): 101-114. https://doi.org/10.1016/j.jfoodeng.2018.09.009

[15] de Frias, J. Atilio, Yaguang Luo, Liping Kou, Bin Zhou, and Qin Wang. "Improving spinach quality and reducing energy costs by retrofitting retail open refrigerated cases with doors." Postharvest Biology and Technology 110 (2015): 114-120. https://doi.org/10.1016/i.postharvbio.2015.06.016

[16] DeVetter, Brent M., Seth Kenkel, Shachi Mittal, Rohit Bhargava, and Tomasz P. Wrobel. "Characterization of the structure of low-e substrates and consequences for IR transflection measurements." Vibrational Spectroscopy 91 (2017): 119-127. https://doi.org/10.1016/j.vibspec.2016.09.001

[17] Han, Jun, Lin Lu, and Hongxing Yang. "Numerical evaluation of the mixed convective heat transfer in a double-pane window integrated with see-through a-Si PV cells with low-e coatings." Applied Energy 87, no. 11 (2010): 34313437. https://doi.org/10.1016/i.apenergy.2010.05.025

[18] Schaefer, C., G. Bräuer, and J. Szczyrbowski. "Low emissivity coatings on architectural glass." Surface and Coatings Technology 93, no. 1 (1997): 37-45. https://doi.org/10.1016/S0257-8972(97)00034-0

[19] Solovyev, A. A., S. V. Rabotkin, and N. F. Kovsharov. "Polymer films with multilayer low-E coatings." Materials Science in Semiconductor Processing 38 (2015): 373-380. https://doi.org/10.1016/j.mssp.2015.02.051

[20] Ghosh, S. S., P. K. Biswas, and S. Neogi. "Thermal performance of solar cooker with special cover glass of low-e antimony doped indium oxide (IAO) coating." Applied Thermal Engineering 113 (2017): 103-111. https://doi.org/10.1016/i.applthermaleng.2016.10.185

[21] Abundiz-Cisneros, N., R. Sanginés, R. Rodríguez-López, M. Peralta-Arriola, J. Cruz, and R. Machorro. "Novel Low-E filter for architectural glass pane." Energy and Buildings 206 (2020): 109558.

https://doi.org/10.1016/i.enbuild.2019.109558 